DOI https://doi.org/10.30525/978-9934-26-047-6-26

\title{
WATER QUALITY OF THE FISH-BREADING PONDS
}

\author{
Soborova O. M. \\ Candidate of Geographical Sciences, \\ Associate Professor at the Aquatic Bioresources and Aquaculture \\ Department \\ Odesa State Environment University
}

Bezyk K. I.

Senior Lecturer at the Aquatic Bioresources and Aquaculture Department Odesa State Environment University

\author{
Kudelina O. Y. \\ Senior Lecturer at the Department of Foreign Languages \\ Odesa State Environment University \\ Odesa, Ukraine
}

As a result of the growth of industrial production, the impact on the environment, including reservoirs and watercourses, has increased. An increase in the volumes of industrial and domestic wastewater discharges causes the changes in the life of the aquatic organisms groups, leads to a deterioration in the water quality. Anthropogenic pollution and water bodies eutrophication on the territory of the settlements develops over time into a rather acute problem. Pollutants affect all components of the aquatic ecosystem, resulting in changing their basic characteristics [1].

Water quality of the fish ponds is characterized by such indicators as temperature, transparency, color, dissolved gases (oxygen, carbon dioxide, ammonia, hydrogen sulfide), hydrogen $(\mathrm{pH})$, organic matter, nutrients (nitrogen, phosphorus), salt composition, number of microorganisms [3].

Industrial fish farming is developing most intensively among the modern forms of commercial fish farming. It is characterized by the commercial fish production in the small fish ponds, mesh cages, circulatory systems, small concrete ponds and other facilities. The main feature of industrial fish farming is a high production intensity. It is provided by a high density of landing, i.e. a fish concentration per unit area and water, a purposeful formation of the water environment, especially a temperature regime, a water gas structure and an intensive water exchange. Also an essential feature of industrial fish farming is using the complete nutrient-balanced 
feed in the form of dry decorated particles (granules, extrudates, cereals and capsules), based on the dry flour-like components [2].

When assessing the environmental risk in conducting the high-intensity pond fish farming, which is the basis of commercial aquaculture in Ukraine, one of the most important issues is to assess their impact on the water quality in the open natural water bodies. On the one hand open natural reservoirs are water sources for fish-breeding enterprises, and on the other hand they serve as a place for water discharging from the fish farms. For example, the heavy metal salts negative effects on fish have been studied well. They can not only be responsible for fish poisoning, but also can cause diseases such as non-parasitic cataracts [3]. In addition, heavy metals accumulate in the fish bodies [3], which certainly reduces a quality of the final fish food products.

In artificial reservoirs (ponds) where the intensive cultivation of aquatic organisms is carried out, an agrobiocenosis with its own specific water quality, which can affect the water quality in a natural water body, is formed. In addition, there is a clear feedback - a quality of water in a natural object directly affects the efficiency of fish farming biotechnology.

Today in Ukraine the traditional objects of aquaculture are carp species: carp, white and variegated silver carp and their hybrids, grass carp. However, other species have recently been actively cultivating: rainbow trout, European catfish, pike, clary catfish, crucian carp, tench, and among the sturgeon species the most common species are: sterlet, Russian sturgeon, sturgeon, beluga, bester, paddlefish. Water quality is one of the main indicators for quality fish farming.

The water of the water source from which the reservoir is filled must meet the following requirements: to meet the biological characteristics of farmed fish species; to provide the marketable fish with marketable qualities; to prevent accumulating the toxic substances in fish; not to contain substances that spoil the fish taste or give the fish an unpleasant odor; should not be a source of fish diseases.

\section{References:}

1. Основы индустриального рыбоводства Електронний ресурс. Режим доступу: https://studfile.net

2. Шекк П.В. Індустріальне рибництво: підручник. Одеса: 2017. $227 \mathrm{c}$.

3. Показатели качества воды прудовых хозяйств и требования, предъявляемые к ним. Електронний ресурс. Режим доступу: https://gidrologia.ru/publikatsii/pokazateli-kachestva-vody-prudovyhhozyaystv-i-trebovaniya-predyavlyaemye-k-nim.html 